\title{
Correction
}

\section{Correction: Identification of Differentially Expressed Genes in Leaf of Reaumuria soongorica under PEG- Induced Drought Stress by Digital Gene Expression Profiling}

\section{The PLOS ONE Staff}

There is an error in the grant number for the funding from State Key Development Program for Basic Research of China. Please refer to the correct funding statement here:

This work was financially supported by the State Key Development Program for Basic Research of China (973 Program, Grant No. 2013CB429904) and the National Natural Science Foundation of China (Grant Nos. 31070358, 30800122). The funders had no role in study design, data collection and analysis, decision to publish, or preparation of the manuscript.

\section{Reference}

1. Liu Y, Liu M, Li X, Cao B, Ma X (2014) Identification of Differentially Expressed Genes in Leaf of Reaumuria soongorica under PEG-Induced Drought Stress by Digital Gene Expression Profiling. PLoS ONE 9(4): e94277. doi:10.1371/journal.pone.0094277
Citation: The PLOS ONE Staff (2014) Correction: Identification of Differentially Expressed Genes in Leaf of Reaumuria soongorica under PEG-Induced Drought Stress by Digital Gene Expression Profiling. PLoS ONE 9(7): e104142. doi:10.1371/ journal.pone.0104142

Published July 28, 2014

Copyright: $\odot 2014$ The PLOS ONE Staff. This is an open-access article distributed under the terms of the Creative Commons Attribution License, which permits unrestricted use, distribution, and reproduction in any medium, provided the original author and source are credited. 